\title{
Maize-common bean/lupine intercrop productivity and profitability in maize-based cropping system of Northwestern Ethiopia
}

\author{
Alemayehu Assefa ${ }^{1 *}$, Tamado Tana ${ }^{2}$, Nigusie Dechassa ${ }^{2}$, Yigzaw Dessalgn ${ }^{3}$, Kinde Tesfaye $^{4}$ \\ and Wortmann C.S ${ }^{5}$
}

${ }^{1}$ Crop Research Directorate, Amhara Region Agricultural Research Institute, P.O. Box 8, Bahir Dar, Ethiopia

${ }^{2}$ School of Plant Science, Haramaya University, P.O. Box 138, Dire Dawa, Ethiopia

${ }^{3}$ LIVE Project, International Livestock Research Institute, P.O. Box 5689, Addis Ababa, Ethiopia

${ }^{4}$ Crop modelling and GIS for Agricultural Systems, International Maize and Wheat Improvement Center, P.O. Box

5689, Addis Ababa, Ethiopia

${ }^{5}$ Agronomy and horticulture, University of Nebraska-Lincoln, P.O. Box 830915, Lincoln, NE 68583-0915, USA

\begin{abstract}
Cereal-legume intercropping is common in Ethiopia but intercropping of common bean and lupine with maize is a recent practice in maize based cropping system of Northwestern Ethiopia. The objective of this study was to determine the appropriate legume species and planting arrangement for higher productivity and profitability of the cropping system. Field experiments were conducted at two sites in Northwestern Ethiopia during the 2012 and 2013 main cropping seasons. Intercropping of common bean (Phaseolus vulgaris L.), narrow-leaf lupine ( $L u$ pinus angustifolius L.), and white lupine (Lupinus albus L.) with maize (Zea mays L.) were conducted under two intercrop planting arrangements (IPA), single row of legume in between maize rows and paired rows of legume in between paired rows of maize and sole cropping of maize as check treatment in randomized complete block design with three replications. Results indicated that maize grain yield was $16 \%$ and $13 \%$ more on maize-narrow leaf lupine intercropping with paired and single row IPA, respectively, relative to sole crop maize. Maize equivalent yield and land equivalent ratio were on average $18 \%$ and $42 \%$, respectively, higher with intercropping compared to sole cropping. Maize-bean with single and paired row IPA, and the maize-narrow leaf lupine with the paired row IPA produced $28 \%, 23 \%$, and $20 \%$ more maize equivalent yield compared to sole crop maize, respectively. The associated increases in net return were $22 \%, 17 \%$, and $15 \%$. The results indicated enhanced productivity and economic return of maize-common bean intercropping, which could be scaled up for increasing household food security.
\end{abstract}

Keywords: Cropping system, Economic return, Maize equivalent yield, Land equivalent ratio, Paired row, Single row.

DOI: http://dx.doi.org/10.4314/ejst.v9i2.1

\section{INTRODUCTION}

Maize (Zea mays) is one of the most important staple food crops and a target of most food security programs in Ethiopia (CSA, 2015). Production of different legumes including common bean, white lupine and narrow leaf lupine as sole crop is expanding in northwestern Ethiopia where narrow leaf lupine is a recent introduction (Likawent
Yeheyis et al., 2012). Grains of common bean and white lupine are used as human consumption while narrow leaf lupine grain as livestock feed with potential alternative to common bean and soybean (Glycine max) for human consumption.

Intercropping is the growing of two or more crops in proximity to promote synergism for increased productivity and cropping system diversity

\footnotetext{
*Corresponding author: alemayehuassefa03@yahoo.com

(C)This is an Open Access article distributed under the terms of the Creative Commons Attribution License (http://creativecommons.org/licenses/CC BY4.0).
} 
(Preston, 2003). Maize-legume intercropping can result in improved soil nutrient and water use, increased productivity, and greater yield stability with reduced risk of crop failure while enabling healthier diets (Elodie et al., 2010; Meighen and Marney, 2012). These advantages are important in low-input, risk vulnerable, and land scarce semi-subsistence farming systems (RezaeiChianeh et al., 2011). Intercropping offers greater financial stability than sole cropping and is easily practiced by labor-intensive smallholder farms (Lithourgidis et al., 2011). Legume intercropping with maize can be a way to grow a staple cereal crop while benefiting from the legume crop (Seran and Brintha, 2010). Intercropping is traditional but often the agronomic aspects are less well understood compared with monoculture systems (Lithourgidis et al., 2011). Intercropping can be a component of highly productive, sustainable and environmentally friendly cropping systems (Crew and Peoples, 2004).

Traditional cereal based cropping systems of Ethiopia are often less efficient than intercropping (Tesfa Bogale et al., 2002). Soil fertility in northwestern Ethiopia is depleted due to continuous cereal production. Most smallholders cannot afford much if any fertilizer application and their farm size is declining with increasing population pressure (Menberu Teshome, 2014). Therefore, intensification of farming systems to feed the increasing population through maizelegume intercropping has potential for enhanced food production. Most of the previous intercrop experiments in Ethiopia were focused on maizebeans intercrop only with single row intercrop planting arrangement, for instance maize-common bean (Tamado Tana and Eshetu Mulatu, 2000; Workayehu Tenaw and Wortmann, 2011), and maize-fababean (Tilahun Tadesse et al., 2012).
Besides, information on maize-lupine intercrop was not available.

The selection of an appropriate intercropping system is quite complex as the success of intercropping systems depend much on the interactions between the component species, the available management practices, and the

environmental conditions (Lithourgidis et al., 2011). Therefore, economically viable intercropping largely depends on adaptation of intercrop pattern and selection of compatible crops (Seran and Brintha, 2009) that maximize positive interaction and minimize competition. In the high lands of central Kenya, intercropping of maize with common bean, cow pea (Vigna unguiculata L.), and groundnut (Arachis hypogaea L.) in paired rows of legume between paired maize rows resulted high crop productivity and economic benefits relative to the conventional intercropping systems of single row of legume in between maize rows (Mucheru-Muna et al., 2010). Thus, field experiment was conducted to determine the appropriate legume species and planting arrangement for higher productivity and profitability of the cropping system.

\section{MATERIALS AND METHODS}

\section{Description of the Study Sites}

The experiment was conducted at research stations on Nitisols at Jabitenan district ( $10.68^{\circ}$ latitude and $37.27^{\circ}$ longitude, 1847 meter elevation) and Mecha district $\left(11.39^{\circ}\right.$ latitude and $37.11^{\circ}$ longitude, 1982 meter elevation) in major maize growing areas of northwestern Ethiopia during the 2012 and 2013 June-October cropping seasons. Both locations 


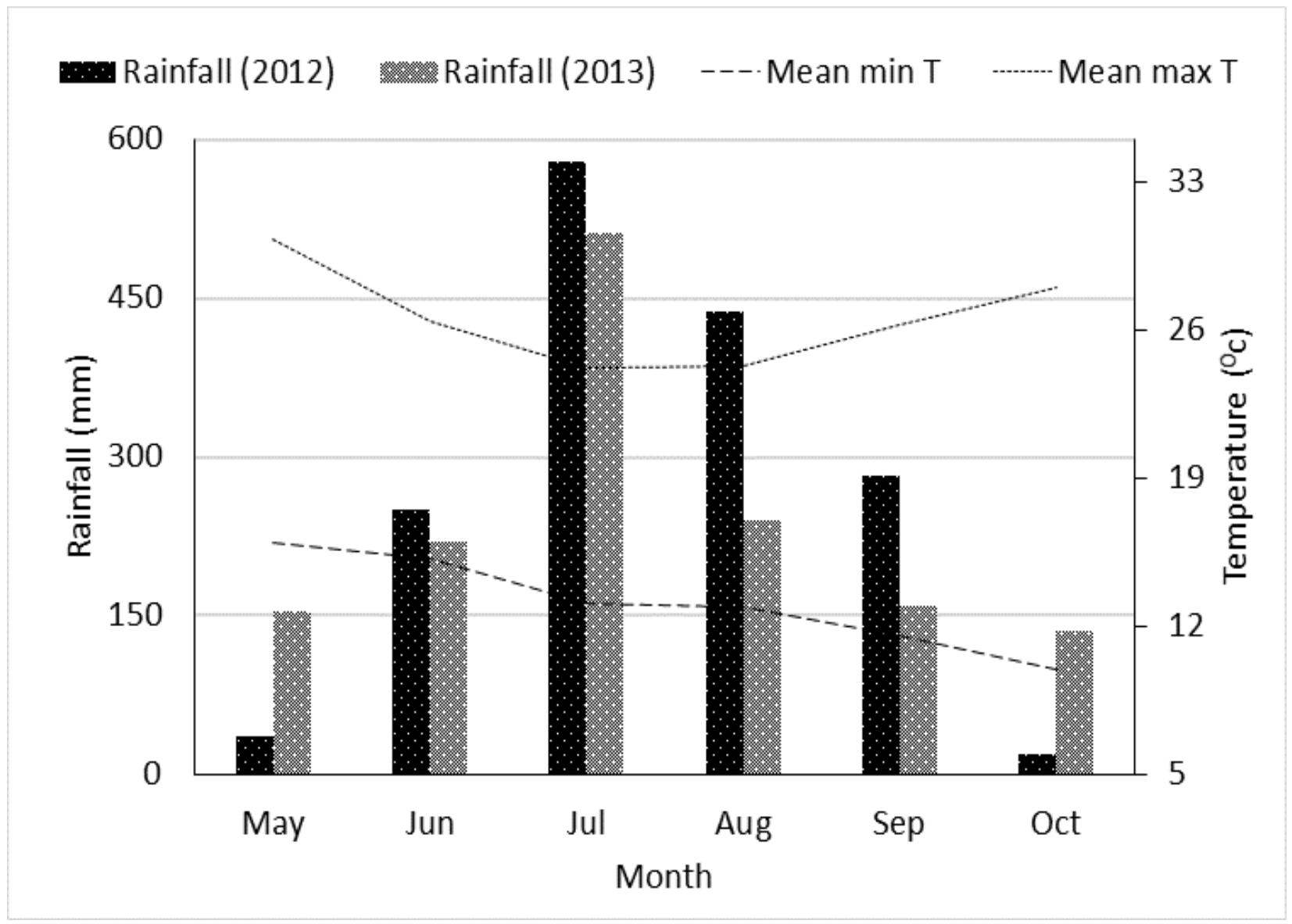

Figure 1. Monthly mean temperature of 2012 and 2013 and rainfall distribution at Mecha experimental site ${ }^{\text {a }}$

${ }^{a}$ Data were not available at Jabitenan.

Source: Meteorology station of Bahir Dar branch

have mono-modal rainfall pattern, approximately $1540 \mathrm{~mm} \mathrm{yr}^{-1}$ with about $90 \%$ falling from June to October at Mecha (Figure 1). The mean maximum and minimum temperature ranged from 24 to $33{ }^{\circ} \mathrm{c}$ and 9 to $15^{\circ} \mathrm{c}$, respectively (Figure 1). The soil sample analysis during experimentation period indicated the sites had clay texture with $\mathrm{pH}$ $\left(\mathrm{H}_{2} \mathrm{O}\right)$ 1:2.5 ranged from 4.7 to 5.0 and available phosphorus (Bray, $\mathrm{mg} \mathrm{kg}^{-1}$ ) ranged from 2.3 to 5.7 .

\section{Treatments and Experimental Design}

The treatments consisted of common bean, narrow leaf lupine and white lupine intercropped with maize and with intercrop planting arrangements (IPA) of a single or paired rows of legume between maize rows or paired of maize rows, respectively and sole crop maize as check treatment. Treatments were laid out in a randomized complete block design with three replications. Sole crop common bean, SC narrow leaf lupine and SC white lupine were included to calculate land equivalent ratio. All crop species were planted on the same date in an additive series with $100 \%$ and $40 \%$ of maize and legume sole crop plant populations, respectively (Woomer et al., 2004). The plots were 6.0 by $3.0 \mathrm{~m}$. Maize row spacing was $75 \mathrm{~cm}$ with single row IPA, and 50 and 112.5 $\mathrm{cm}$ within and between paired rows with paired 


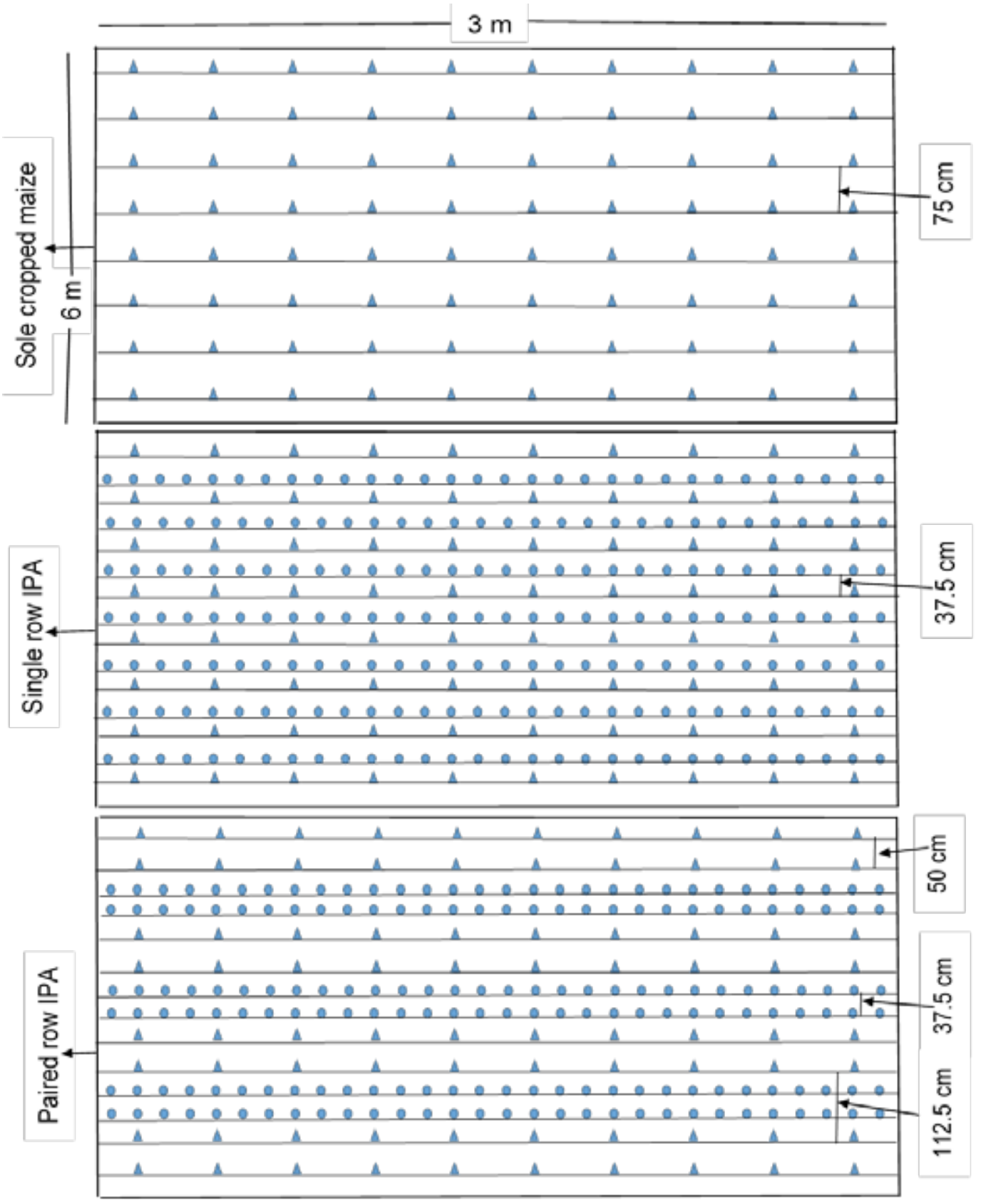

$\Delta \_$Maize row, spacing between maize plants within a row $=30 \mathrm{~cm}$ $\therefore$ Legume row, spacing between legume plants within a row $=10 \mathrm{~cm}$

Figure 2. Experimental field layout for single and paired row intercrop planting arrangement (IPA) in comparison to sole crop maize

row IPA, respectively. The legume rows were planted $37.5 \mathrm{~cm}$ from maize rows. Within row plant spacing was 30 and $10 \mathrm{~cm}$ for maize and legumes, respectively (Figure 2).

\section{Experimental Materials and Procedures}

The crop varieties were $B H 540$ (average maturity period 145-days) for maize, Chore (average maturity period 95-days) for bean, Sanabor (average maturity period 112-days) for narrow 
leaf lupine, and a local cultivar (average maturity period 150-days) for white lupine. At planting, urea $(46 \% \mathrm{~N})$ and Di-ammonium phosphate (DAP, $18 \% \mathrm{~N}, 20 \% \mathrm{P}$ ) were band applied at $43 \mathrm{~kg} \mathrm{~N}$ and $40 \mathrm{~kg} \mathrm{P} \mathrm{ha}^{-1}$ under maize furrows of both sole crop and intercrop at depth of 7-cm and mixed thoroughly with the soil. Similarly, $41 \mathrm{~kg} \mathrm{~N}$ and 20 $\mathrm{kg} \mathrm{P} \mathrm{ha-1}$ were applied for sole crop common bean. No fertilizer was applied for intercrop legumes and sole crop lupines. Two seeds for each crop species were placed per hill manually in the furrow, and thinned to one plant at three weeks after planting. Urea was side-dressed to the side of maize rows at $85 \mathrm{~kg} \mathrm{~N} \mathrm{ha}^{-1}$ during the 8- to 10-leaf stage. Weeds were controlled by hand hoeing and weeding during the season as required.

\section{Method of Data Collection and Measurements}

Leaf area index of maize was determined using nondestructive sampling from five plants at the silking stage in the net plot. The product of the length and widest width of individual maize leaves multiplied by 0.75 was used to estimate individual leaf area (Dwyer and Stewart, 1986), and the total leaf area of the five plants divided by the area of land occupied was used to calculate maize leaf area index (Watson, 1947). Maize grain yield was determined from whole plants in the middle four rows of $1.8 \mathrm{~m}$ length. Plant height, above ground biomass yield, and ear plant ${ }^{-1}$ were determined at physiological maturity from 10 randomly sampled maize plants in the middle four rows of $1.8 \mathrm{~m}$ length. Biomass was weighed three weeks after sun drying with average air temperature of $28{ }^{\circ} \mathrm{C}$. Harvest index was calculated as grain yield divided by above ground biomass. Ten randomly sampled ears were used to determine kernel ear ${ }^{-1}$. Thousand kernel weight of maize was determined from randomly sampled grains at moisture content of $12.5 \%$.
For the legume component, yield related traits of legumes (seed and pods plant ${ }^{-1}$, above ground biomass, plant height) were determined from ten randomly sampled plants in the net plot. Ten randomly sampled pods were used to determine seeds $\operatorname{pod}^{-1}$. Hundred seed weight of legume was determined from randomly sampled grains at moisture content of $10 \%$. Grain yield for the legumes was determined from middle three and seven rows of $1.8 \mathrm{~m}$ length for the intercrop and sole crop plots, respectively. Grain moisture content was measured using a grain moisture tester (Dickey-John Multigrain) and final grain yield was adjusted to the moisture contents of $12.5 \%$ for maize and $10 \%$ for legumes.

\section{Intercrop Competition, and Yield Gain/Loss}

Competition between component crops was measured by competitive ratio (CR), to indicate the number of times by which one component is more competitive than the other (Willey and Rao, 1980).

$$
\begin{aligned}
& C R_{M L}=\left(L E R_{M} / L E R_{L}\right) x\left(Z_{L M} / Z_{M L}\right) \\
& C R_{L M}=\left(L E R_{L} / L E R_{M}\right) x\left(Z_{M L} / Z_{L M}\right)
\end{aligned}
$$

where $\mathrm{CR}_{\mathrm{ML}}=$ competitive ratio of maize in the intercrop; $\mathrm{CR}_{\mathrm{LM}}=$ competitive ratio of legume in the intercrop; $\mathrm{LER}_{\mathrm{M}}=$ land equivalent ratio of maize; $\mathrm{LER}_{\mathrm{L}}=$ land equivalent ratio of legume; $\mathrm{Z}_{\mathrm{ML}}=$ plant proportion of maize in the intercrop, $Z_{M L}=M_{P P I C} / T_{P P I C}=0.31, \mathrm{M}_{\mathrm{PPIC}}=$ maize plant population in the intercrop plot, $\mathrm{T}_{\text {PPIC }}=$ total plant population (maize + legume) in the intercrop plot; $\mathrm{Z}_{\mathrm{LM}}=$ plant proportion of legume in the intercrop, $Z_{L M}=L_{P P I C} / T_{P P I C}=0.69, \mathrm{~L}_{\text {PPIC }}=$ legume plant population in the intercrop plot. 
The proportionate yield loss or gain of the component crops on a plant basis in comparison to the respective sole crop was determined by the actual yield loss index (AYLI) index (Banik, 1996).

$$
\begin{aligned}
& A Y L I_{M L}=L E R_{M} x\left(M_{P P S C} / M_{P P I C}\right)-1 \\
& A Y L I_{L M}=L E R_{L} x\left(L_{P P S C} / L_{P P I C}\right)-1
\end{aligned}
$$

Where $\mathrm{AYLI}_{\mathrm{ML}}=$ actual yield loss index (-) or gain $(+)$ per plant of maize in the intercrop; $\mathrm{AYLI}_{\mathrm{LM}}=$ actual yield loss (-) or gain $(+)$ per plant of legume in the intercrop; $\mathrm{M}_{\mathrm{PPSC}}=$ plant population of maize in the sole crop, $\mathrm{M}_{\mathrm{PPSC}}=44444$ plants ha ${ }^{-1}, \mathrm{~L}_{\mathrm{PPSC}}=$ plant population of legume in the sole crop, $\mathrm{L}_{\mathrm{PPSC}}=$ 250000 plants ha-1.

\section{Evaluation of System Productivity}

Intercrop productivity was determined in two ways; land equivalent ratio (LER) (Willey, 1979) and maize equivalent yield (MEY) (Verma and Modgal, 1983). Land equivalent ratio is the amount of land required in sole cropping to obtain the same yield as in the intercrop. $L E R=\left(Y_{M L} / Y_{M}\right)+\left(Y_{L M} / Y_{L}\right)$, where $\mathrm{Y}_{\mathrm{ML}}=$ intercrop maize grain yield ha ${ }^{-1} ; Y_{M}=$ sole crop maize grain yield ha ${ }^{-1} ; Y_{L M}=$ intercrop legume grain yield ha${ }^{1} ; \mathrm{Y}_{\mathrm{L}}=$ sole crop legume grain yield $\mathrm{ha}^{-1}$. Maize equivalent yield is the sum of maize yield in the intercrop system and the converted legume yield, and was compared with sole crop maize yield. Maize was the main crop, therefore, yield of the legumes in the intercrop system was converted to maize yield by multiplying the legume yield with legume/maize price ratio.

$M E Y=Y_{M L}+\left(Y_{L M} x P_{L} / P_{M}\right)$, where; $\mathrm{P}_{\mathrm{L}}=$ price of legume grain $\mathrm{kg}^{-1} ; \mathrm{P}_{\mathrm{M}}=$ price of maize grain $\mathrm{kg}^{-1}$.

\section{Data Analysis}

Data analysis for intercrop experiments was conducted according to Walter (1993) using generalized linear model (GLM) procedure of the statistical analysis system (SAS) 9.4 version (SAS Institute, 2013) for each sites. Finally, the data were combined over sites and years since values for error mean square of the two sites were homogeneous (Gomez and Gomez, 1984). In the combined analysis, year was considered as a random variable and site as a fixed variable. Crop parameters that showed statistical significance due to treatments effects (combination of legume species and IPA including sole crop maize) were further tested using single degree of freedom orthogonal contrasts to determine the significance of each factor. Mean separation for significant responses were compared using SAS least square means (LSMEANS) test (probability of difference, PDIFF) at $\mathrm{P}=0.05$.

\section{Economic Analysis}

Economics of the intercropping system was analyzed following a partial budget procedure of International Maize and Wheat Improvement Center (CIMMYT, 1988) at three scenarios based on the existing trend in increasing cost of production. Three cost/price ratios as labor cost man-day ${ }^{-1 /}$ bean grain price $\mathrm{kg}^{-1}$ of 5,8 and 11, and labor cost man-day ${ }^{-1} /$ lupines grain price $\mathrm{kg}^{-1}$ of 13,21 and 29 were assumed. Labor cost included costs for planting, harvesting, threshing, and cleaning grain required for the intercropped legume species. The labor cost during experimentation period of the year 2013 was Ethiopian Birr (ETB) 40 man-day $^{-1}$ (1120 ETB ha ${ }^{-1}$ ). In addition, the costs of legume seeds as planting materials were included as a vari- 
able cost. Grain prices used for the determination of cost price ratio were ETB 4.5, 8.0 and $3.0 \mathrm{~kg}^{-1}$ for maize, common bean, and lupines, respectively based on the local market prices of the months from December to February of 2013/14. Cost price ratios were calculated by dividing labor cost manday $^{-1}$ with grain prices of legumes $\mathrm{kg}^{-1}$, keeping legume grain price constant while labor cost manday $^{-1}$ increased from 40 to 64 and to 88 ETB. The net return was calculated by deducting labor cost and seed cost of legumes from the gross return. Marginal rate of return for each treatment was calculated by deducting the net return of the treatment from the sole crop maize and then divided by the cost incurred for the treatment.

\section{RESULTS AND DISCUSSION}

\section{Maize Yield and Yield Related Traits}

Maize leaf area index (LAI), plant height, thousand kernel weight (TKW), harvest index (HI) and grain yield were significantly affected by the growing seasons. Higher LAI and plant height were recorded in 2012 compared to in 2013 (Table 1), which might be due to variations in rainfall distribution between the two years where there was high amount of rainfall from June to September in 2012 compared to 2013 (Figure 1). Whereas high value of TKW, HI and grain yield were recorded in 2013 compared to in 2012 (Table 1). These low values in 2012 were due to moisture deficiency during grain filling stage of maize in October 2012 at Mecha (Figure 1).

Maize leaf area index was significantly $(\mathrm{P}<0.05)$ affected by treatments and was highest for the sole crop maize (Figure 3). The reduction in maize leaf area index for the intercrop treatments might be due to competition for growth resources. Contrary to this finding, Ranbir et al. (2001) reported significantly more leaf area index for the intercropped maize with soybean (Glycine max), cowpea (Vigna unguiculata L.), french bean (Phaseolus vulgaris L.) and urd bean (Vigna mungo) relative to the

Table 1. Effect of growing seasons on growth, yield and yield components of maize under maize-legume intercropping in Northwestern Ethiopia ${ }^{\mathrm{a}}$

\begin{tabular}{lllllll}
\hline Growing season & $\begin{array}{l}\text { Leaf } \\
\text { index }\end{array}$ & area & $\begin{array}{l}\text { Plant height } \\
(\mathrm{cm})\end{array}$ & $\begin{array}{l}\text { Thousand } \\
\text { weight }(\mathrm{g})\end{array}$ & $\begin{array}{l}\text { kernel } \\
\text { Harve s t } \\
\text { index }\end{array}$ & $\begin{array}{l}\text { Grain yield } \\
\left(\mathrm{t} \mathrm{ha}^{-1}\right)\end{array}$ \\
\hline 2012 & $4.28^{\mathrm{a}}$ & $234^{\mathrm{a}}$ & $220^{\mathrm{b}}$ & $0.31^{\mathrm{b}}$ & $5.31^{\mathrm{b}}$ \\
2013 & $4.06^{\mathrm{b}}$ & $224^{\mathrm{b}}$ & $312^{\mathrm{a}}$ & $0.40^{\mathrm{a}}$ & $6.67^{\mathrm{a}}$ \\
\hline PDIFF & $*$ & $* *$ & $* * *$ & $* * *$ & $* * *$ \\
$\mathrm{CV}(\%)$ & 8.79 & 3.01 & 8.72 & 13.08 & 14.77 \\
\hline
\end{tabular}

\footnotetext{
${ }^{\text {a }}$ Data were combined over sites (Jabitenan and Mecha)

Numbers followed by different letters on the same column indicated significant difference at the 5\% probability level. $*$, ** and $* * *$ indicate significant difference at the probability level $0.05,0.01$ and 0.001 , respectively.
} 


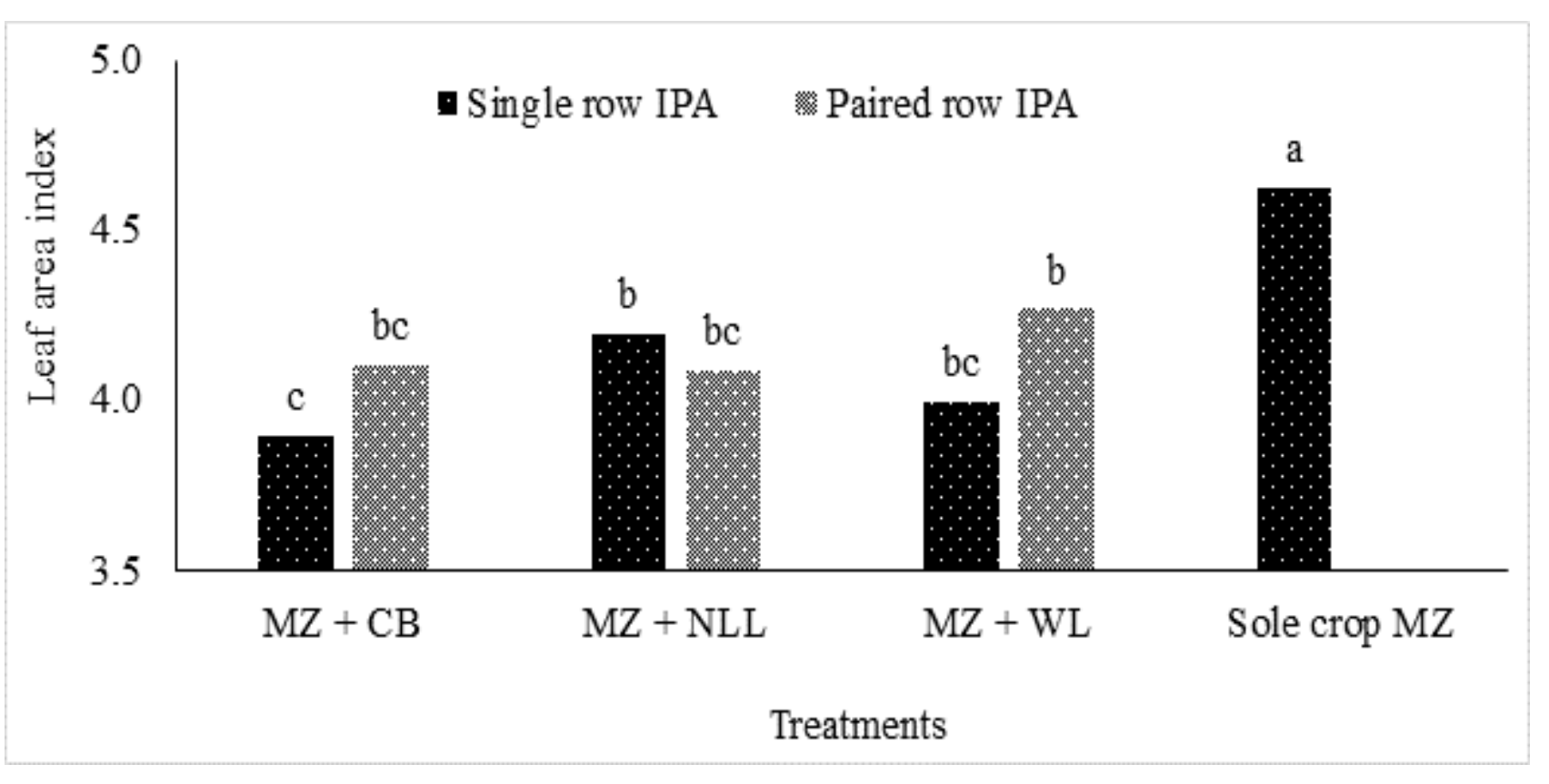

Figure 3. Effect of intercrop legume species and single compared with paired row of intercrop planting arrangement on maize leaf area index in northwestern Ethiopia ${ }^{a}$

${ }^{a}$ Data were combined over sites (Jabitenan and Mecha) and years (2012 and 2013)

Bars followed by different letters indicate significant differences at the $5 \%$ probability level.

Note: $\mathrm{MZ}$ - maize; CB - common bean; NLL - narrow leaf lupine; WL - white lupine; and IPA - intercrop planting arrangement.

maize sole crop. Treatments did not significantly affect maize plant height, thousand kernel weight, biomass yield, ear plant ${ }^{-1}$, kernel ear $^{-1}$ and harvest index. Thousand kernel weight ranged from $258 \mathrm{~g}$ for maize in sole crop to $274 \mathrm{~g}$ for the narrow leaf lupine intercrop. Maize biomass yield and number of kernels ear ${ }^{-1}$ were ranged from $15.33 \mathrm{t} \mathrm{ha}^{-1}$ and 389 for the white lupine intercrop to $18.41 \mathrm{t} \mathrm{ha}^{-1}$ and 417 for the narrow leaf lupine intercrop, respectively. Plant height, harvest index and number of ears plant ${ }^{-1}$ ranged from 226 to $231 \mathrm{~cm}, 0.33$ to 0.38 and 1.0 to 1.1 , respectively.

Maize grain yield over years at Mecha were significantly $(\mathrm{P}<0.05)$ affected by the treatments (Table 2). The highest maize grain yield (7.27 t ha$\left.{ }^{1}\right)$ at Jabitenan and $6.14 \mathrm{t} \mathrm{ha}^{-1}$ at Mecha were obtained from the narrow leaf lupine intercropping with paired row IPA and single row IPA, respectively. The respective yield advantages were 14\% and $24 \%$ relative to sole-cropped maize. Combined over sites maize grain yield was 16 and $13 \%$ more on maize-narrow leaf lupine intercropping with paired and single row IPA, respectively, relative to sole crop maize (Table 2). The higher yield of intercropped maize than sole-cropped maize might be due to transfer of fixed nitrogen from intercropped narrow-leaf lupine to maize crop. Yield increase of the intercropped maize might be also due to interspecific facilitation or complementarity in root interactions between the intercropped maize and legume species, and also phosphorus solubilized by the legumes. The increased in maize yield in the intercrop system was agreeing with other results (Li et al., 2007; Tilahun Tadesse et al., 2012; Amini et al., 2013). Palmason et al. 
(1992) reported significant $\mathrm{N}$ transfer from narrow-leaf lupine to intercropped rye grass (Lolium multiflorum). Li et al. (2007) and Tilahun Tadesse et al. (2012) reported an increase in grain yield of intercropped maize with faba bean compared to sole cropped maize. Li et al. (2007) confirmed that the over yielding of intercropped maize was resulted from its uptake of phosphorus mobilized by the acidification of the rhizosphere via faba bean root release of organic acids and protons.

Increase in grain yield for intercropped maize with soybean compared to sole cropped maize was also reported by Amini et al. (2013). The greater soil exploration and compatibility of the spatial root distribution of intercropped species (Li et al.,
2006), and enhanced $\mathrm{N}$ and $\mathrm{P}$ uptake by maize (Fusuo and Long, 2003; Li et al., 2007) might have led to yield increments in the intercropped maize in maize-faba bean intercropping. Ghosh et al. (2006) reported that great improvement in the intercropped sorghum yield in the sorghum-soybean intercropping was due to positive changes in below ground (root biomass, root length density, nitrate reductase activity in root, soil microbial biomass and dehydrogenase activity). Wilson (1988) also reported that the roots had a greater effect than shoots on plant growth and resource capture of the intercrop system. However, maize-sunflower intercrop (Amini et al., 2013), maize-bean and maize-cowpea intercrop at proportion of 100:50 (Saban et al., 2008), maize-mustard intercrop (Ti-

Table 2. Effect of intercropped legumes and planting arrangement on maize grain yield at Jabitenan and Mecha in Northwestern Ethiopia ${ }^{a}$

\section{Treatments}

Planting arrangement $\quad$ Over

sites

Intercrop

Jabitenan

Mecha

\begin{tabular}{|c|c|c|c|c|}
\hline \multirow[b]{2}{*}{ Maize + Common bean } & \multirow[b]{2}{*}{ Single row IPA } & \multicolumn{2}{|c|}{$\mathrm{tha}^{-1}$} & \multirow[b]{2}{*}{5.86} \\
\hline & & 5.87 & $5.85^{\mathrm{ab}}$ & \\
\hline Maize + Common bean & Paired row IPA & 5.89 & $5.44^{\mathrm{ab}}$ & 5.66 \\
\hline Maize + Narrow leaf lupine & Single row IPA & 6.67 & $6.14^{\mathrm{a}}$ & 6.40 \\
\hline Maize + Narrow leaf lupine & Paired row IPA & 7.27 & $5.83^{\mathrm{ab}}$ & 6.55 \\
\hline Maize + White lupine & Single row IPA & 6.08 & $5.01^{\mathrm{ab}}$ & 5.54 \\
\hline Maize + White lupine & Paired row IPA & 6.83 & $5.65^{\mathrm{ab}}$ & 6.24 \\
\hline Sole crop maize & & 6.37 & $4.96^{\mathrm{b}}$ & 5.66 \\
\hline \multicolumn{2}{|l|}{ PDIFF } & & & \\
\hline CV $(\%)$ & & 12.72 & 17.06 & 14.77 \\
\hline
\end{tabular}

\footnotetext{
${ }^{\text {a }}$ Data were combined over years (2012 and 2013)
}

Numbers followed by different letters on the same column indicated significant difference at the $5 \%$ probability level using SAS LSMEANS test.

Note: IPA is intercrop planting arrangement; and * is significant difference at probability level of 0.05 . 
lahun Tadesse et al., 2007), and maize-peanut, maize-cowpea and maize-bean intercrop at proportion of 100:100 (Ossom and Rhykerd, 2007) negatively affected intercropped maize yield relative to the sole crop maize.

\section{Yield and Yield Related Traits of Legume Species}

Yield and yield related traits of intercropped legumes were significantly affected by the treatments (Table 3). Plant height, biomass yield, hundred seed weight and pods plant ${ }^{-1}$ were highest in case of white lupine whereas seeds plant ${ }^{-1}$ and grain yield were highest in common bean. Pods and seeds plant $^{-1}$ and grain yield of narrow leaf lupine were significantly higher in paired row IPA compared to single row IPA (Table 3). This significant increase in pod and seeds plant $^{-1}$ and grain yield of narrow leaf lupine in paired row IPA compared to single row IPA might be due to decreased in competitive ratio of maize from 25 to 16 as indicated in Table 4 and also might be due to more light penetration in the paired row IPA. Woomer et al. (2004) reported that solar radiation available to the legume understory on maize-common bean intercrop increased by $54 \%$ in paired row compared to single row IPA. Number of pods and seeds plant ${ }^{-1}$ and grain yield of intercropped narrow leaf lupine were highly reduced relative to the sole crop whereas these crop parameters were highest for sole crop narrow leaf lupine compared to sole crop of common bean and white lupine (Table 3 ). The highest reduction in pod and seeds plant ${ }^{-1}$ and grain yield of narrow leaf lupine in the intercrop system relative to the sole crop indicated that the narrow leaf lupine was less competitive than white lupine and common bean. Biomass and grain yield for the intercropped

Table 3. Yield and yield related traits of the legumes in single and paired row planting arrangement under maizecommon bean/lupine intercropping in Northwestern Ethiopia ${ }^{a}$

\begin{tabular}{|c|c|c|c|c|c|c|c|}
\hline \multicolumn{2}{|l|}{ Treatments } & & \multirow{2}{*}{$\begin{array}{l}\text { Hundred } \\
\text { seed weight } \\
\text { (g) }\end{array}$} & \multirow{2}{*}{$\begin{array}{l}\text { Biomass } \\
\text { yield (t } \\
\left.\text { ha }^{-1}\right)\end{array}$} & \multirow[b]{2}{*}{$\begin{array}{l}\text { Grain } \\
\text { yield } \\
\left(\mathrm{t} \mathrm{ha}^{-1}\right)\end{array}$} \\
\hline Intercrop & $\begin{array}{l}\text { Planting } \\
\text { arrangement }\end{array}$ & $\begin{array}{l}\text { height } \\
(\mathrm{cm})\end{array}$ & $\begin{array}{l}\text { Pods } \\
\text { plant }^{-1}\end{array}$ & $\begin{array}{l}\text { Seeds } \\
\text { plant }^{-1}\end{array}$ & & & \\
\hline Maize + CB & Single row IPA & $48^{\mathrm{c}}$ & $11^{\text {ab }}$ & $54^{\mathrm{a}}$ & $23^{\mathrm{b}}$ & $1.34^{\mathrm{b}}$ & $0.79^{\mathrm{a}}$ \\
\hline Maize + CB & Paired row IPA & $45^{c}$ & $11^{\mathrm{ab}}$ & $54^{\mathrm{a}}$ & $22^{\mathrm{bc}}$ & $1.25^{\mathrm{b}}$ & $0.74^{\mathrm{a}}$ \\
\hline Maize + NLL & Single row IPA & $57^{\mathrm{b}}$ & $6^{c}$ & $24^{\mathrm{d}}$ & $20^{c}$ & $0.58^{\mathrm{c}}$ & $0.24^{c}$ \\
\hline Maize + NLL & Paired row IPA & $56^{\mathrm{b}}$ & $9^{b}$ & $37^{c}$ & $20^{c}$ & $0.99^{\mathrm{bc}}$ & $0.38^{\mathrm{b}}$ \\
\hline Maize + WL & Single row IPA & $145^{\mathrm{a}}$ & $11^{\mathrm{ab}}$ & $42^{\mathrm{bc}}$ & $35^{\mathrm{a}}$ & $3.92^{\mathrm{a}}$ & $0.44^{\mathrm{b}}$ \\
\hline Maize + WL & Paired row IPA & $144^{\mathrm{a}}$ & $12^{\mathrm{a}}$ & $47^{\mathrm{ab}}$ & $35^{\mathrm{a}}$ & $4.32^{\mathrm{a}}$ & $0.47^{\mathrm{b}}$ \\
\hline \multirow{2}{*}{\multicolumn{2}{|c|}{$\begin{array}{l}\text { PDIFF } \\
\text { CV }(\%)\end{array}$}} & *** & $* *$ & **** & $* * *$ & & \\
\hline & & 6.91 & 24.41 & 25.88 & 9.20 & 25.22 & 25.83 \\
\hline \multicolumn{2}{|c|}{ Sole crop common bean } & 50 & 11 & 58 & 21 & 2.38 & 1.86 \\
\hline \multirow{2}{*}{\multicolumn{2}{|c|}{ Sole crop narrow leaf lupine }} & 49 & 17 & 73 & 20 & 2.99 & 2.12 \\
\hline & & 135 & 15 & 64 & 28 & 10.56 & 1.14 \\
\hline
\end{tabular}

${ }^{a}$ Data were combined over sites (Jabitenan and Mecha) and years (2012 and 2013)

Numbers followed by different letters on the same column indicated significant difference at the $5 \%$ probability level.

Note: IPA is intercrop planting arrangement; CB is common bean; NLL is narrow leaf lupine; WL is white lupine;

. *, ** and $* * *$ are significant difference at probability level of $0.05,0.01$ and 0.001 , respectively. 
Table 4. Competitive ratio and actual yield loss index from maize-legume intercropping in single and paired row intercrop planting arrangement in northwestern Ethiopia ${ }^{\mathrm{a}}$

\begin{tabular}{llcccc} 
Treatments & \multicolumn{2}{c}{ Competitive ratio } & \multicolumn{2}{c}{ Actual yield loss index } \\
\hline Intercrop & Planting arrangement & $\mathrm{CR}_{\mathrm{ML}}$ & $\mathrm{CR}_{\mathrm{LM}}$ & $\mathrm{AYLI}_{\mathrm{ML}}$ & $\mathrm{AYLI}_{\mathrm{LM}}$ \\
\hline Maize + CB & Single row IPA & 5.80 & 0.18 & +0.04 & +0.06 \\
Maize + CB & Paired row IPA & 6.01 & 0.18 & -0.01 & +0.01 \\
Maize + NLL & Single row IPA & 24.97 & 0.05 & +0.14 & -0.69 \\
Maize + NLL & Paired row IPA & 15.63 & 0.08 & +0.14 & -0.49 \\
Maize + WL & Single row IPA & 6.48 & 0.18 & -0.01 & -0.02 \\
Maize + WL & Paired row IPA & 6.22 & 0.17 & +0.08 & +0.03
\end{tabular}

${ }^{a}$ Data were combined over sites (Jabitenan and Mecha) and years (2012 and 2013)

Note: IPA is intercrop planting arrangement; $\mathrm{CR}_{\mathrm{ML}}$ is competitive ratio of maize in the intercrop; $\mathrm{CR}_{\mathrm{LM}}$ is competitive ratio of legumes in the intercrop; $\mathrm{AYLI}_{\mathrm{ML}}$ is actual yield loss index of maize in the intercrop; $\mathrm{AYLI}_{\mathrm{LM}}$ is actual yield loss index of legumes in the intercrop; CB is common bean; NLL is narrow leaf lupine; and WL is white lupine.

legumes were generally lowest relative their sole crop partly due to plant population that was $40 \%$ of sole-cropped.

\section{Competition between Component Crops}

Maize was more competitive than all the legumes as competitive ratio of maize was greater than one whereas legumes competitive ratios were less than one (Table 4). The competitive ratio of maize ranged from 5.80 to 24.97 whereas competitive ratio of legumes ranged from 0.05 to 0.18 . The highest and lowest competitive ratio of maize and legume, respectively occurred in maize-narrow leaf lupine intercrop with single row IPA. The high competitive ratio of maize in all intercrop treatments agreed with results of Saban et al. (2008) who reported higher competitive ratio of maize compared to common bean and cow pea in maize-common bean and maize- cow pea intercropping. Maize actual yield gain per plant basis (14\%) and yield loss of narrow leaf lupine $(69 \%)$ was recorded in maize-narrow leaf lupine intercrop with single row IPA. Yield gain on maize in most of the intercrop treatments might be due to high competitive ratio of maize compared to legumes. The actual yield loss index gave more precise information about the nature of competition and the behavior of each species in the intercropping system (Banik, 1996) indicating yield loss or gain on the basis of its sign as well as values. Maize yield gain in most maize-common bean and maize-cow pea intercrop treatments were reported by Saban et al. (2008). Similarly Chui and Richard (1984) reported reduction in soybean yield by association with maize due to reduction in dry matter accumulation and pods plant ${ }^{-1}$ in the maize-soybean intercrop relative to sole-cropped soybean. 


\section{Maize-Legume Intercrop Productivity}

Land equivalent ratio was more than unity, ranging from 1.3 to 1.5. The highest land equivalent ratio was recorded for maize-common bean and maize-white lupine intercrop with single and paired row IPA, respectively, and the lowest for maize-narrow leaf lupine with single row IPA. Land equivalent ratio is directly related to the actual yield gain or loss of the component crops in the system relative to their sole crop. The highest land equivalent ratio for maize-common bean with single arrangement and maize-white lupine with paired arrangement was associated to actual yield gain of the component crops in the intercrop system while for maize-narrow leaf lupine intercropping the yield gain of maize was associated with yield loss of narrow leaf lupine resulted relatively lowest land equivalent ratio. On the average the intercrop system was $42 \%$ more productive compared to sole crop production as measured by land equivalent ratio, agreed with Saban et al. (2008), and Tilahun Tadesse et al. (2012). Saban et al. (2008) reported 47 and 56\% more productive of the maize-common bean and maize-cow pea intercrop, respectively, relative to sole crop production. Similarly, maize-fababean intercrop was $11 \%$ productive relative to sole crop production as reported by Tilahun Tadesse et al. (2012).

The intercrop system was significantly productive relative to sole crop system (Figure 4) with yield advantage of $18 \%$ as expressed by maize equivalent yield. The highest maize equivalent yield for the intercrop was due to an additional yield of the legumes and the relative increase in maize grain yield in the intercrop treatments compared to sole crop. This is consistent with studies by Cardoso et al. (2007) who found higher maize equivalent yield relative to sole-cropped maize in maize-common bean intercrop system. Within intercrop system, maize equivalent yield was significantly affected by interactions of legume species and planting arrangement with highest productivity for maize-common bean intercrop combined with a single row IPA (Figure 4). Maize equivalent yield was $28 \%$ higher on maize-common bean intercrop with single row IPA relative to sole-cropped maize.

The paired row IPA gave better intercrop productivity compared to single row IPA in maizelupines but not in maize-common bean intercrop as shown in Figure 4. Common bean is high nitrogen demanding relative to lupines, therefore, the higher productivity of maize-common bean intercrop in single row IPA might be due to better access of nitrogen fertilizer applied on maize rows to common bean as it uptakes $\mathrm{N}$ from two adjacent maize rows in contrast to paired rows where a common bean plant uptake $\mathrm{N}$ only from one maize row as clearly indicated in Figure 2. The higher productivity of maize-lupines intercrop in pared IPA was consistent with Woomer et al. (2004) and Mucheru-Muna et al. (2010) who reported the paired planting arrangement also known as MBILI (Managing Beneficial Interactions in Legume Intercrops) system was superior with robust improvements in crop yields and economic benefits relative to the conventional single IPA in maize-legume intercropping system. Woomer et al. (2004) demonstrated more light penetration, which likely benefits the maize as well as the legume, but also suggested that superior crop yields in the MBILI system were related to additional advantages in root distribution and reduced belowground competition. The MBILI system clearly increased intercrop productivity due to the spatial arrangement of the crops and the actual yield gain index. 


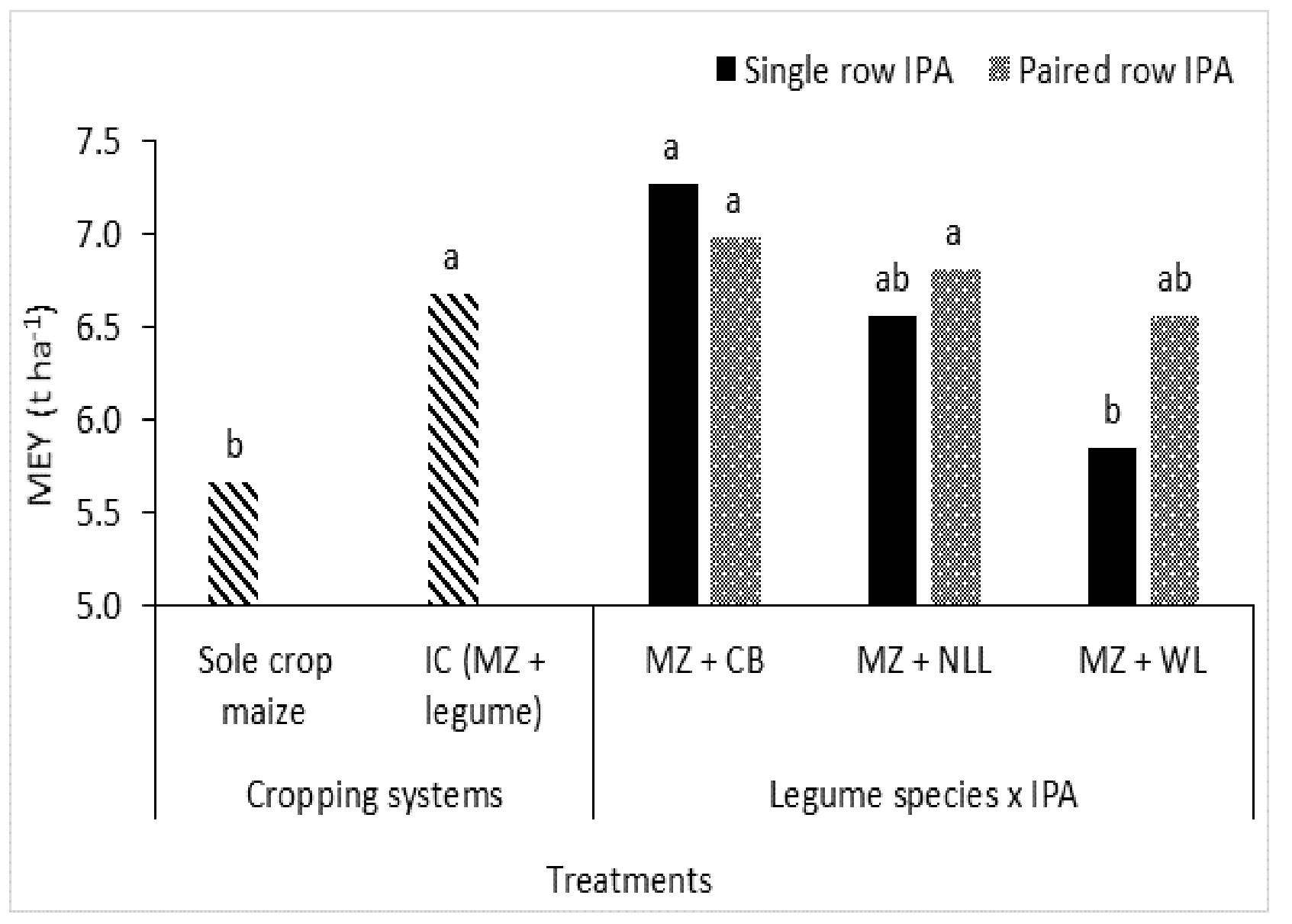

Figure 4. Effect of legumes and planting arrangement on intercrop productivity as expressed by maize equivalent yield (MEY) in Northwestern Ethiopia ${ }^{a}$

${ }^{a}$ Data were combined over sites (Jabitenan and Mecha) and years (2012 and 2013).

Bars followed by different letters indicate significant differences at the $5 \%$ probability level.

Note: MZ - maize; CB - common bean; NLL - narrow leaf lupine; WL - white lupine; and IC - intercrop; IPA - inter-

crop planting arrangement.

\section{Economic Returns from Maize-Legume}

\section{Intercrop}

All intercrop treatments, but maize-white lupine intercrop with single row IPA, were economically feasible relative to sole-cropped maize for all labor cost to legume grain price ratios (Table 5). Highest net return and marginal rate of return were obtained from maize-common bean with single IPA, maize-common bean with paired IPA, and maize-narrow leaf lupine intercrop with paired IPA (Table 5). The respective monetary advantages were 22\% (5627 ETB ha-1), 17\% (4387 ETB ha ${ }^{-1}$ ) and $15 \%$ (3893 $\mathrm{ETB} \mathrm{ha}^{-1}$ ) relative to sole-cropped maize. Monetary advantage from the intercrop system decreased as labor cost to legume grain price ratio increased; for instance in maize-common bean intercrop with single IPA monetary advantage decreased from $22 \%$ to $17 \%$ as labor cost to bean price ratio increased from 5 to 11 . The intercrop system was economically feasible relative to sole crop maize as reported from different intercrop studies including SegunOlasanmi and Bamire (2010) (maize-cowpea), Addo-Quaye et al. (2011) (maize-soybean), and Workayehu Tenaw and Wortmann (2011) (maizecommon bean). 
Table 5. Net return and marginal rate of return from maize-legume intercropping in single and paired row planting arrangements in Northwestern Ethiopia ${ }^{\mathrm{a}}$

The cost of one man-day of labor expressed in terms of $\mathrm{kg}$ of common bean and lupine grain price, respectively for three cost price ratios

\begin{tabular}{|c|c|c|c|c|c|c|c|}
\hline \multicolumn{2}{|l|}{ Treatments } & \multicolumn{2}{|c|}{ CPR I (5 and 13) } & \multicolumn{2}{|c|}{ CPR II (8 and 21) } & \multicolumn{2}{|c|}{ CPR III (11 and 29) } \\
\hline Intercrop & $\begin{array}{l}\text { Planting } \\
\text { arrangement }\end{array}$ & $\begin{array}{l}\text { NR } \\
\left(\mathrm{ETB} \mathrm{ha}^{-1}\right)\end{array}$ & $\begin{array}{l}\text { MRR } \\
(\%)\end{array}$ & $\begin{array}{l}\text { NR } \\
\left(\mathrm{ETB} \mathrm{ha}^{-1}\right)\end{array}$ & $\begin{array}{l}\text { MRR } \\
(\%)\end{array}$ & $\begin{array}{l}\text { NR } \\
\left(\mathrm{ETB} \mathrm{ha}^{-1}\right)\end{array}$ & $\begin{array}{l}\text { MRR } \\
(\%)\end{array}$ \\
\hline Maize + CB & Single row IPA & 31117 & 364 & 30445 & 224 & 29773 & 148 \\
\hline Maize + CB & Paired row IPA & 29877 & 284 & 29205 & 168 & 28533 & 105 \\
\hline Maize + NLL & Single row IPA & 28301 & 228 & 27629 & 112 & 26957 & 57 \\
\hline Maize + NLL & Paired row IPA & 29383 & 316 & 28711 & 169 & 28039 & 99 \\
\hline Maize + WL & Single row IPA & 24991 & -39 & 24319 & -60 & 23647 & -70 \\
\hline Maize + WL & Paired row IPA & 28215 & 213 & 27543 & 105 & 26871 & 53 \\
\hline Sole crop maize & & 25490 & & 25490 & & 25490 & \\
\hline
\end{tabular}

${ }^{\text {a }}$ Data were combined over sites (Jabitenan and Mecha)

Note: CPR - cost price ratio, including labor cost to common bean price, and labor cost to lupines price; ETB - Ethiopian Birr; NR - net return; MRR - marginal rate of return; IPA - intercrop planting arrangement; CB - common bean; NLL - narrow leaf lupine; and WL- white lupine.

\section{CONCLUSION}

Maize-common bean with single and paired rows, and maize-narrow leaf lupine with paired row intercrop planting arrangements offer much opportunity to smallholder farmers for increasing productivity and economic return of their cropping systems. Maize-common bean intercropping could be scaled up in the study areas for increasing household food security. Further study is required to evaluate more legume species which can be compatible to maize intercrop system.

\section{ACKNOWLEDGMENTS}

This work was supported by SIMLESA (Sustainable Intensification of Maize-Legume Cropping Systems for Food Security in Eastern and Southern Africa) project; A Borlaug LEAP Fellowship 2013 sponsored travel to University of Nebraska-Lincoln, USA for data analysis and advisory support; The Amhara Agricultural Research Institute, specifically Adet Agricultural Research Center, facilitated the research work. 


\section{REFERENCES}

Addo-Quaye, A.A., Darkwa, A.A and Ocloo, G.K. (2011). Yield and productivity of component crops in a maize-soybean intercropping system as affected by time of planting and spatial arrangement. Journal of Agricultural and Biological Science 6(9): 50-57.

Amini, R., Shamayeli, M.A and Dabbagh, M.N. (2013). Assessment of yield and yield components of corn (Zea mays L.) under two and three strip intercropping systems. International Journal of Bioscience 3(3):65-70.

Banik, P. (1996). Evaluation of wheat (T. aestivum) and legume intercropping under $1: 1$ and $2: 1$ row-replacement series systems. Journal of Agronomy and Crop Science 176: 289-294.

Cardoso, E.J.B.N., Nogueira, M.A and Ferraz, S.M.G. (2007). Biological $\mathrm{N}_{2}$ fixation and mineral $\mathrm{N}$ in common bean-maize intercropping or sole cropping in southeastern Brazil. Experimental Agriculture 43: 319-330.

Chui, I.A.N and Richard, S. (1984). Influence of spatial arrangements of maize on performance of an associated soybean intercrop. Field Crops Research 8: 187-198.

CIMMYT (International Maize and Wheat ImprovementCenter).(1988).FromAgronomic Data to Farmer Recommendations: An Economic Training Manual. Revised Edition. Mexico, D.F.

Crew, T.E and Peoples, M.B. (2004). Legume versus fertilizer source of nitrogen: ecological tradeoffs and human needs. Agriculture, Ecosystems and Environment 102: 279-297.

CSA (Central Statistical Agency). (2015). Area, production and yield of crops for private peasant holdings for meher season 2014/2015 (2007 E.C). Addis Ababa, Ethiopia.

Dwyer, L.M and Stewart, D.W. (1986). Leaf area development in field-grown maize. Agronomy Journal 78: 334-343.

Elodie, B., Bruno, C., Eric, J., Gérard, S and Philippe, H. (2010). P for two-intercropping as a means to better exploit soil $\mathrm{P}$ resources under low input conditions. 19 $^{\text {th }}$ World Congress of Soil Science, Soil Solutions for a Changing World. Brisbane, Australia. Published on DVD. 218-220.

Fusuo, Z and Long, L. (2003). Using competitive and facilitative interactions in intercropping systems enhances crop productivity and nutrient-use efficiency. Plant and Soil 248: 305-312.

Ghosh, P.K., Manna, M.C., Bandyopadhyay, K.K, Ajay, T.A.K., Wanjari, R.H., Hati, K.M., Misra, A.K., Acharya, C.L and Subba, R.A. (2006). Inter-specific interaction and nutrient use in soybean-sorghum intercropping system. Agronomy Journal 98: 1097-1108.

Gomez, K.A and Gomez, A.A. (1984). Statistical procedures for agricultural research. John Wiley and Sons: New York.

Li, L., Jian-Hao, S., Fusuo, Z and Tianwen, G. (2006). Root distribution and interactions between intercropped species. Oecologia 147: 280-290.

Li, L., Shu-Min, L., Jian-Hao, S., Li, L.Z., XingGuo, B., Hong-Gang, Z and Fu-Suo, Z. (2007). Diversity enhances agricultural productivity via rhizosphere phosphorus facilitation on phosphorus-deficient soils. Proceedings of the National Academy of Sciences of the United States of America 104 (27): 11192-11196. 
Likawent Yeheyis, Claudia, K., Firew Tegegn and Kurt, J.P. (2012). Sweet Blue Lupine (Lupinus angustifolius L.) seed as a substitute for concentrate mix supplement in the diets of yearling Washera rams fed on natural pasture hay as basal diet in Ethiopia. Tropical Animal Health and Production 44: 1255-1261.

Lithourgidis, A.S., Dordas, C.A., Damalas, C.A and Vlachostergios, D.N. (2011). Annual intercrops: an alternative pathway for sustainable agriculture. Australian Journal of Crop Science 5(4): 396-410.

Meighen, W and Marney, E.I. (2012). Effects of shade on nitrogen and phosphorus acquisition in cereal-legume intercropping systems. Agriculture 2: 12-24.

Menberu Teshome. (2014). Population growth and cultivated land in rural Ethiopia: Land use dynamics, access, farm size, and fragmentation. Resources and Environment 4(3): 148-161.

Mucheru-Muna, M., Pieter, P., Daniel, M., James, K., Jayne, M., Roel, M and Bernard, V. (2010). A staggered maize-legume intercrop arrangement robustly increases crop yields and economic returns in the highlands of Central Kenya. Field Crops Research 115:132-139.

Ossom, E.M and Rhykerd, R.L. (2007). Effects of corn (Zea mays L.) and grain legume associations on soil mineral nutrient concentration, soil temperature, crop yield, land equivalent ratio and gross income in swaziland. African Crop Science Conference Proceedings 8: 225-230.

Palmason, F., Danso, S.K and Hardarson, A. (1992). Nitrogen accumulation in sole and mixed stands of sweet-blue lupine (Lupinus angustifolius L.) ryegrass and oats. Plant and Soil 142: 135-142.

Preston, S. (2003). Appropriate technology transfer for rural areas (ATTRA): Intercropping principles and production practices.

Agronomy systems guide. US Department of Agriculture. www.attra,ncat.org..

Ranbir, S.R., Bhupinder, S and Negi, S.C. (2001). Management of maize/legume intercropping under mid-hill sub-humid conditions. Indian Journal Agricultural Research 35(2): 100-103.

Rezaei-Chianeh, E., Dabbagh, M.N.A., Shakiba, M.R., Ghassemi-Golezani, K., Aharizad, S and Shekari, F. (2011). Intercropping of maize (Zea mays L.) and faba bean (Vicia faba L.) at different plant population densities. African Journal of Agricultural Research 6(7): 17861793.

Saban, Y., Mehmet, A and Mustafa, E. 2008. Identification of advantages of maize-legume intercropping over solitary cropping through competition indices in the East Mediterranean region. Turk Journal of Agriculture 32: 111-119.

SAS (Statistical Analysis System) Institute. (2013).

SAS/AF® 9.4 Procedure guide, Second Edition. Cary, NC, USA.

Segun-Olasanmi, A.O and Bamire, A.S. (2010). Analysis of costs and returns to maize-cowpea intercrop production in Oyo state, Nigeria. Poster presented at the joint $3^{\text {rd }}$ African Association of Agricultural Economists (AAAE) and $4^{\text {th }}$ Agricultural Economists Association of South Africa (AEASA) Conference, Cape Town, South Africa, September 19-23, 2010.

Seran, T.H and Brintha, I. (2009). Studies on determining a suitable pattern of capsicum (Capsicum annum L.)-vegetable cowpea (Vigna unguiculata L.) intercropping. Karnataka Journal of Agricultural Science 22: 1153-1154.

Seran, T.H and Brintha, I. (2010). Review on maize based intercropping. Journal of Agronomy 9: 
$135-145$.

Tamado Tana and Eshetu Mulatu. (2000). Evaluation of sorghum, maize and common bean cropping system in East Hararghe, Eastern Ethiopia. Ethiopian Journal of Agricultural Science 17 (1/2): 33-46.

Tesfa Bogale, Tolessa Debele, Setegn Gebeyehu, Tamado Tana, Negash Geleta and Workayehu Tenaw. (2002). Development of appropriate cropping systems for various maize producing regions of Ethiopia. In: Proceedings of the Second National Maize Workshop of Ethiopia, pp. 61-70, Addis Ababa, Ethiopia.

Tilahun Tadesse, Minale Liben and Alemayehu Assefa. (2007). Evaluation of maize (Zea mays)gomenzer (Brasica carinata) intercropping under different plant proportion and planting method of gomenzer. In: Proceedings of the $1^{\text {st }}$ Annual Regional Conference on Completed Crop Research Activities, pp. 52-59, Amhara Regional Agricultural Research Institute. Bahir Dar, Ethiopia.

Tilahun Tadesse, Minale Liben and Alemayehu Assefa. (2012). Role of maize (Zea mays L.)fababean (Vicia faba L.) intercropping planting pattern on productivity and nitrogen use efficiency of maize in Northwestern Ethiopia highlands. International Research Journal of Agricultural Science and Soil Science 2(3): 102-112.

Verma, S.P and Modgal, S.C. (1983). Production potential and economics of fertilizer application as resource constraints in maize-wheat crop sequence. Himachal Journal of Agricultural Research 9: 89-92.

Walter, T.F. (1993). Statistical design and analysis for intercropping experiments. Volume $\mathrm{I}$ : Two crops. New York: Springer-Verlag.
Watson, D.J. (1947). Comparative physiological studies in the growth of field crops. I. Variation in net assimilation rate and leaf area between species and varieties, and within and between years. Annals of Botany 11:41-76.

Willey, R.W and Rao, M.R. (1980). A competitive ratio for quantifying competition between intercrops. Experimental Agriculture 16: 117125.

Willey, R.W. (1979). Intercropping - its importance and research needs. Field Crops Research 32: $1-10$.

Wilson, J.B. (1988). Shoot competition and root competition. Journal of Applied Ecology 25: 279-296.

Woomer, P.L., Langat, M and Tungani, J.O. (2004). Innovative maize-legume intercropping results in above- and below-ground competitive advantages for understory legumes. West African Journal of Applied Ecology 6: 85-94.

Workayehu Tenaw and Wortmann, C.S. (2011). Maize-bean intercrop weed suppression and profitability in Southern Ethiopia. Agronomy Journal 103 (4): 1058-1063. 